\section{NOBEL PRIZES}

\section{Neurophysiologists Honoured}

WITH the nows from Stockholm last week that the Nobel prize for medicine had been awarded to the neurophysiologists, Professor Ulf von Euler, Dr Julius Axelrod and Sir Bernard Katz, the wheel has, in a sense, turned full circle. Sir Henry Dale and Otto Loewi were awarded the prize in 1936 for showing that nervous impulses travel through the nervous system in two different ways. In 1963, Eccles, Hodgkin and Huxley were similarly honoured for their part in unravelling the first of these two systems-the electrical transmission of the impulse along the nerve fibre. And now von Euler, Axelrod and Katz share this year's prize, worth $£ 32,000$, for their separate work on the second puzzle-how nerve impulses are transmitted chemically across the minute insulating gaps, or synapses, which separate nerve from nerve or nerve from muscle.

Professor Ulf Svante von Euler, 65, was born in Stockholm and has spent most of his scientific life at the Royal Karolinska Institute, where he is now professor of physiology. In the early 1930s he worked for a time at University College, London, where a major influence was Sir Henry Dale. Von Euler's chief contribution to neurophysiology is his demonstration in 1947 that the transmitter substance which diffuses from the ends of stimulated sympathetic nerve to bridge the synaptic gap is the catecholamine, noradrenaline.

Von Euler's work cleared the ground for the later studies of Julius Axelrod. Born in New York City in 1912, Axelrod was trained both as a biochemist and as a pharmacologist, and is now chief of the section of pharmacology at the National Institute of Mental Health, Bethesda, Maryland. After investigating the metabolism of drugs and the function of the pineal gland, he became interested in the fate of the noradrenaline molecule after it had been discharged into the synaptic gap. Clearly the molecule would have to be inactivated after passing on its message, or the nervous system would be thrown into chaos, just as would a tclcphone exchange if all the plugs were left connected after the calls had ended. Axelrod discovered two control mechanisms; an enzyme, catechol-o-methyl transferase which methylates and destroys the noradrenaline molecule, and a process found only at sympathetic nerve endings by which discharged noradrcnaline molecules are reabsorbed by the nerve endings.

Whereas von Euler and Axelrod have been concerned with the transmission of nervous impulses mediated by noradrenaline-the adrenergic nervous system-Sir Bernard Katz has devoted his energies to nervous transmission mediated by acetylcholine-the cholinergic nervous system. His work has led to the important conclusion that synaptic gaps are bridged in essentially the same manner in all parts of the nervous system.

Bernard Katz was born in Leipzig, Germany, in 1911. In 1935 he fled from the Nazis to London, beginning his studies on nerve and muscle function under the supervision of Nobel laureate A. V. Hill at University College, London, where he is now head of the biophysics department. Working initially on the cat neuromuscular junction, and later on giant nerve cells from the squid, Sir Bernard has used micro- electrodes, fine glass electrodes which can be inserted into single cells, to study the electrical behaviour of nerve endings. He has shown that the transmitter substance, acetylcholine, is contained in small vesicles at the nerve endings. In the resting state a very small number of these vesicles are discharged spontancously, but when a nervous impulse reaches the nerve ending many millions of acetylcholine molecules are released to bridge the synaptic gap between the nerve ending and the adjacent cell. More recently, Sir Bernard has been working on the role of calcium ions in the release of acetylcholine.

In announcing the awards, the Royal Karolinska Institute, Stockholm, said the three scientists had "greatly stimulated the search for remedies against nervous and mental disturbances". Whilst drugs tailored to cure mental illness may be far in the future, no one can deny that the work of von Euler, Axelrod and Katz has led to a new understanding of the nervous system and its chemistry.

\section{FORESTRY}

\section{English Elm Threatened}

Trre future of the elm tree in Britain looks bleak unless the epidemic of Dutch elm disease, at present ravaging the British population of Ulmus procera, is quickly checked. The disease was first recorded in Britain in 1927, but was a comparatively minor problem until two years ago, when, helped perhaps by a series of fine summers, the present epidemic exploded. Dr John Gibbs of the Forestry Commission Research Centre described the current situation as "devastation, with more than sixty per cent of the elm population destroyed in some areas".

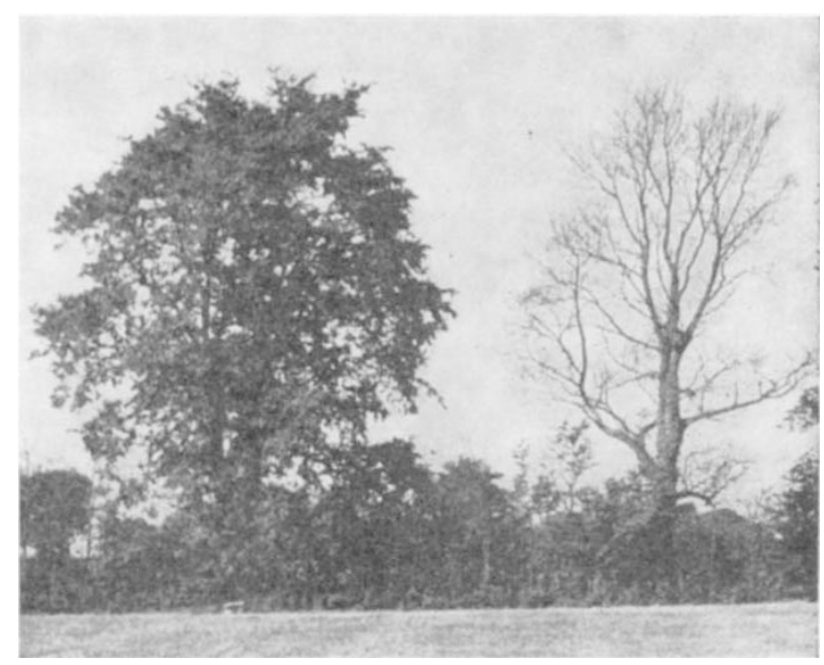

Hedgerow elms blighted by Dutch elm disease. On the left, a healthy elm; on the right, a newly killed tree left gaunt and leafless by the disease.

Dutch elm disease is caused by the fungus Ceratocystis ulmi, but the infection is carried and spread by the elm bark beetles Scolytus scolytus and $S$. multistriatus. The sticky fungal spores become attached to the body of the bectle and are transferred from in- 